\title{
Analysis of Shiitake Environmental Performance via Life Cycle Assessment
}

\author{
Rungnapa Tongpool and Patcharaporn Pongpat
}

\begin{abstract}
Shiitake (Lentinula edodes) is one of the most popular mushrooms in the world. Shiitake farms in Thailand used the sawdust transported for a long distance. Waste management of spent substrate bags is in environmental concern. Energy is also needed for sterilization process. Therefore the environmental performance of shiitake was evaluated in this work using life cycle assessment method. We found that shiitake caused relatively high environmental impacts, compared to everyday vegetables. The impacts in the categories of fossil depletion, climate change and terrestrial acidification caused by $1 \mathrm{~kg}$ shiitake were $0.59 \mathrm{~kg}$ oil equivalent, $1.87 \mathrm{~kg} \mathrm{CO}_{2}$ equivalent and $0.02 \mathrm{~kg} \mathrm{SO}_{2}$ equivalent, respectively. The main impact contributions came from (i) production of sugar and rice bran used as a substrate, (ii) transportation of sawdust and firewood used as a substrate and fuel (iii) fuel burning during sterilization and (iv) burning of spent bags and neck rings. If the sawdust was transported in the distance of $\mathbf{1 0 0}$ $\mathrm{km}$ and if the spent bags and neck rings were not burnt but used for plastic recycling, the impacts of 52,58 and $30 \%$ of fossil depletion, climate change and terrestrial acidification can be reduced, respectively.
\end{abstract}

Index Terms-Climate change, environment, LCA, shiitake.

\section{INTRODUCTION}

Shiitake (Lentinula edodes) is one of the most popular mushrooms in the world. The production amount is second only to the button mushroom (Agaricus bisporus). It has high nutritional value and medicinal properties [1]. Traditionally it is grown on wooden logs but in these days plastic bags filled with substrates are popular [2], [3] as it can be harvested faster [4].

Shiitake is one of the most expensive edible mushroom in Thailand. It is used for several kinds of food e.g., soup, fried shiitake, sauces, chili pastes. The environmental performance of shiitake will influence the environmental performance of food. As it is mainly grown in the north of Thailand due to the weather, some of the substrate components have to be transported from the south and middle parts of the country. Unlike everyday vegetables, energy is needed to sterilize the substrate of shiitake. Waste management of spent plastic bags is also environmental concern [5]. In Thailand, it was reported that shiitake of 0.1-0.4 $\mathrm{kg}$ can be harvested from 1 $\mathrm{kg}$ of substrate bag [6] which is the same as that in China $(0.25-0.3 \mathrm{~kg} / \mathrm{kg}$ substrate bag) [2]. It can be seen that

Manuscript received April 25, 2013; revised June 15, 2013. This work was supported in part by the National Science and Technology Development Agency (NSDTA) Thailand, under the Thailand National LCI Database Project.

The authors are with the National Metal and Materials Technology Center, Pathumthani, 12120 Thailand (e-mail: rungnapt@mtec.or.th, patcharp@mtec.or.th). resources are used and emissions are released from shiitake production. We cannot find any work reporting environmental performance of shiitake production and we think there are rooms for improvement. Three shiitake farms in Thailand were used as a case study in this work. Life cycle assessment (LCA) method was applied to quantify environmental impacts of shitake production. LCA considers aspects of ecosystem, human health, and resources from product's life cycle, i.e., from the stages of raw material provision, production, and use, to disposal and recycling. This can avoid problem-shifting, for example, from one phase of the life cycle to another, from one region to another, or from one environmental problem to another [7]. The methodology of LCA has been explained in details elsewhere [7]-[9].

\section{MATERIALS AND MethodS}

\section{A. Goal}

This work aims to find out the stages of shitake production that contribute the highest environmental impacts. Two approaches to improve environmental performance of shiitake were selected and the potential impact reductions were quantified. The results of this work would be helpful to shiitake and mushroom farmers in becoming more competitive in the green and global market. The reduction of environmental impacts of shitake will also improve environmental performance of the food having shitake as an ingredient.

\section{B. The System and Data under Study}

The scope of the study covered production of raw materials (e.g., substrate, chemicals), transportation of raw materials to the farms and cultivation process, i.e., a cradle-to-gate study, as shown in Fig. 1. The cultivation process comprises substrate preparation, bag filling, sterilization, inoculation, incubation, fruiting and harvesting. Waste management of spent substrate bags was also included.

The substrates for shitake comprise sawdust, rice bran, magnesium sulfate, gypsum, lime, brown sugar and water. Trucks were used to carry the substrate ingredients and the other inputs to the farms. After mixing, they were put into a heat-resistant plastic bag. The bag was closed with a neck ring. Then they were sterilized using a steam for 2-4 hr. A firewood and a sawdust were used as fuel for steam generation. The temperature in the chamber was kept at $85-100{ }^{\circ} \mathrm{C}$. When it was cooled to room temperature, the spawn was put inside the bag and incubated for 3-4 months. After primordia formation and fruiting, shiitake was 
harvested. The neck ring was reused until it was worn out. The spent substrates were used as fertilizer whereas the spent bags and neck rings were burnt.

The data of input and output of shiitake production were collected from the three farms (gate-to-gate inventories) in Chiangmai and Lampang provinces which are in the northern part of Thailand and shown in Table I. The amount of each input and output could not be disclosed, due to confidentiality agreements. The amounts of $\mathrm{CH}_{4}$ and $\mathrm{N}_{2} \mathrm{O}$ from firewood combustion for steam generation were obtained by calculation using the emission factors from IPCC 2006 [10]. The amount of $\mathrm{CO}_{2}$ from the firewood combustion was not included in the inventory since wood absorbs $\mathrm{CO}_{2}$ from the atmosphere. Data on emissions of $\mathrm{CO}, \mathrm{SO}_{2}, \mathrm{NOx}$, NMVOC and PM10 were calculated using emission factors from EMEP/EEA air pollutant emission inventory guidebook 2009 [11]. The impacts from buildings and machinery related to the production were negligible, as large amounts of the shiitake were produced in their lifetimes [8]. In 2012, the annual production of the first, second and third farms were
9.0, 9.0, 4.5 ton, respectively. The obtained input and output were weighted averaged according to the annual production.

The inputs of the gate-to-gate inventory were traced back to their background data to obtain cradle-to-gate inventory, consisting of emissions and natural resources used to produce the inputs. The background data of tap water, electricity, plastic bag and transportation were provided by Thailand national LCI database. The background data for inoculation loop, rubber band and spawn could not be found; therefore, they were excluded from the study. The background data of rice bran was obtained from the inventories of rice milling of Nadsathaporn [12] and paddy rice cultivation of Ecoinvent database in SimaPro 7.2.3 software [13]. Firewood was treated as natural resource whereas sawdust was treated as waste. Thus there was no environmental burden from firewood and sawdust production. The background data of the other materials and plastic bag burning were obtained from Ecoinvent database, where fuel, electricity and tap water in the inventories were replaced by the inventories of Thailand national LCI database.

Natural resources

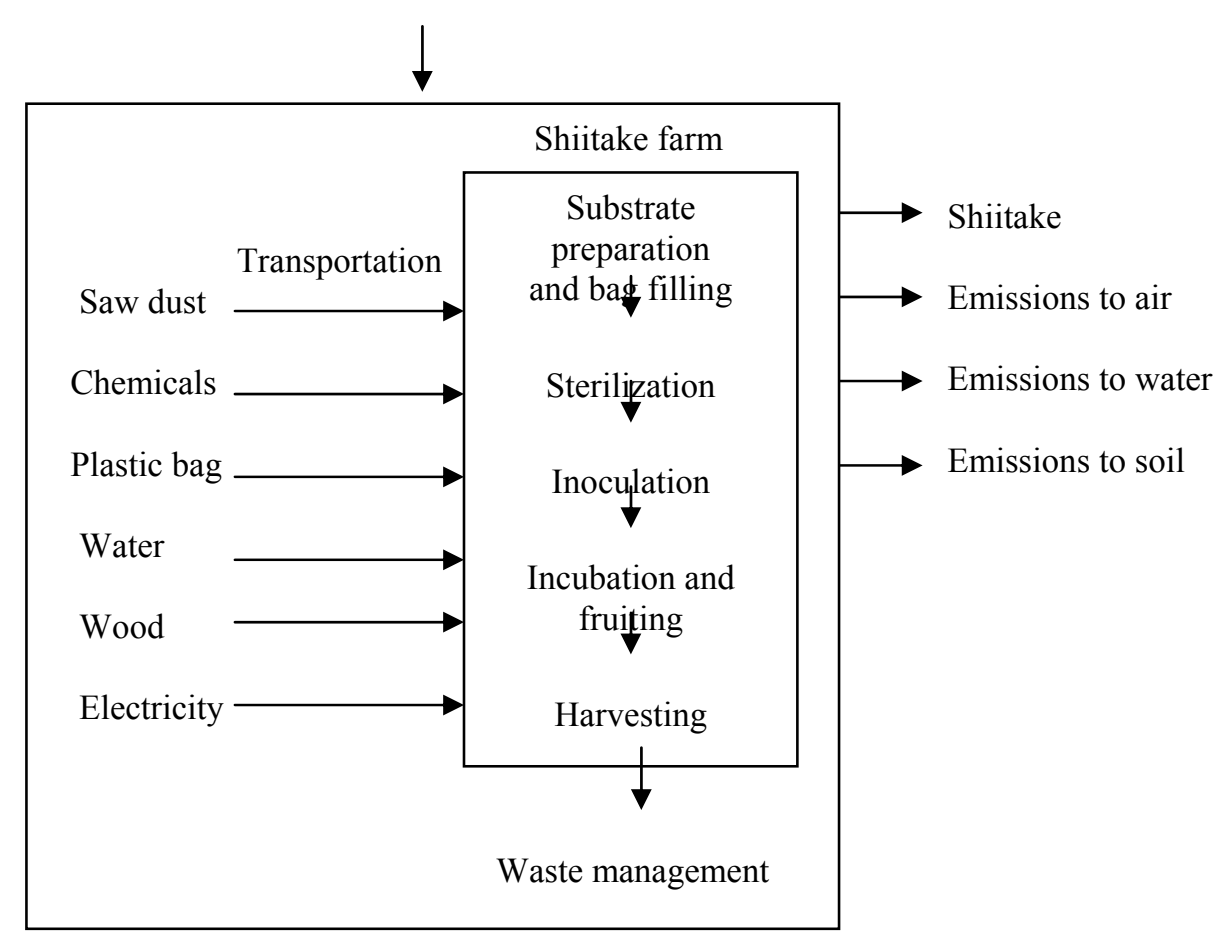

Fig. 1. Boundary of the product systems under LCA study.

TABLE I: GATE TO GATE INVENTORY OF SHIITAKE PRODUCTION

\begin{tabular}{|c|c|c|}
\hline Process & Input & Output \\
\hline Substrate preparation & $\begin{array}{l}\text { Sawdust, Rice bran, Water, Magnesium sulfate, } \\
\text { Gypsum, Lime, Brown sugar, Plastic bag, Neck ring, } \\
\text { Rubber band, Electricity, Transportation of the inputs }\end{array}$ & \\
\hline Sterilization & $\begin{array}{l}\text { Firewood, Sawdust, Water, Transportation of the } \\
\text { firewood and sawdust }\end{array}$ & $\mathrm{CH}_{4}, \mathrm{~N}_{2} \mathrm{O}, \mathrm{NOx}, \mathrm{CO}, \mathrm{SO}_{2}, \mathrm{NMVOC}, \mathrm{PM} 10$ \\
\hline Inoculation & $\begin{array}{l}\text { Inoculation loop, Spawn, Transportation of the loop and } \\
\text { spawn }\end{array}$ & Inoculation loop \\
\hline Incubation and fruiting & Lime, Water, Electricity, Transportation of lime & Lime, Water \\
\hline Harvest & Plastic bag, Transportation of plastic bag & Spent substrate, Spent bag, Spent neck ring \\
\hline
\end{tabular}


Environmental burden from transportation of raw materials were included in the cradle-to-gate inventory. The sawdust used as substrate was transported from neighboring province and the southern part of the country. Chemicals, plastic bag and neck ring were transported from Bangkok. Firewood used for steam generation in sterilization process was locally supplied.

\section{Environmental Impact Assessment}

After the cradle-to-gate inventory was obtained, the classification and characterization methods of ReCiPe Midpoint [14] were applied via SimaPro 7.2.3 software. The impact categories of concern in this study are the following:

1) climate change, represented by the amount of carbon dioxide equivalent $\left(\mathrm{CO}_{2}\right.$ eq),

2) ozone depletion, represented by the amount of trichlorofluoromethane equivalent (CFC-11 eq),

3) terrestrial acidification, represented by the amount of sulfur dioxide equivalent $\left(\mathrm{SO}_{2} \mathrm{eq}\right)$,

4) human toxicity, represented by the amount of 1,4-dichlorobenzene equivalent (1,4-DB eq),

5) photochemical oxidant formation, represented by the amount of non-methane volatile organic compound equivalent (NMVOC eq),

6) particulate matter formation, represented by the amount of PM10 equivalent (PM10 eq),

7) terrestrial ecotoxicity, represented by the amount of 1,4-DB eq,

8) freshwater ecotoxicity, represented by the amount of 1,4-DB eq,

9) marine ecotoxicity, represented by the amount of 1,4-DB eq,

10) fossil depletion, represented by the amount of crude oil equivalent (oil eq).

Following the assessment results, two approaches to improve environmental performance of shiitake were selected, and potential impact reductions were assessed.

\section{RESULTS}

The results of environmental impact assessments of shiitake are shown in Table II. It can be seen that $1 \mathrm{~kg}$ of shiitake production caused potential impacts of $1.87 \mathrm{~kg} \mathrm{CO}_{2}$ eq, $0.02 \mathrm{~kg} \mathrm{SO}_{2}$ eq and $0.59 \mathrm{~kg}$ oil eq in the categories of climate change, terrestrial acidification and fossil depletion, respectively. The impact of climate change of shiitake was higher than those of tomato, onion, bush bean $\left(0.5 \mathrm{~kg} \mathrm{CO}_{2}\right.$ eq $/ \mathrm{kg})$, baby corn $(0.3 \mathrm{~kg} \mathrm{CO} 2 \mathrm{eq} / \mathrm{kg})$ and potato $\left(0.1 \mathrm{~kg} \mathrm{CO}_{2}\right.$ eq $/ \mathrm{kg}$ ) [15]. In the category of terrestrial acidification, the impact of shiitake was about 10-20 times of tomato, onion, bush bean, baby corn and potato $\left(0.001-0.002 \mathrm{~kg} \mathrm{SO} \mathrm{S}_{2} \mathrm{eq} / \mathrm{kg}\right)$. The impact of fossil depletion of shiitake was about 8-19 times of tomato, onion, bush bean, baby corn and potato (0.03-0.07 kg oil eq/kg) [15]. In Thailand, mushrooms are used to cook meat-like food for vegetarian. The impact of climate change of shiitake is lower than those of beef (9-129 $\mathrm{kg} \mathrm{CO} 2 \mathrm{eq} / \mathrm{kg}$ ), poultry (2-6 kg CO $2 \mathrm{eq} / \mathrm{kg}$ ), pork (4-11 kg $\mathrm{CO}_{2} \mathrm{eq} / \mathrm{kg}$ ), egg (2-6 kg $\mathrm{CO}_{2} \mathrm{eq} / \mathrm{kg}$ ) and seafood from aquaculture (3-15 $\mathrm{kg} \mathrm{CO}$ eq/ $\mathrm{kg}$ ) [16]. If a few percentage of meat diet is replaced by shiitake, environmental impacts around the world would be largely reduced.

The contributions of environmental impacts from shiitake production are shown in Fig. 2. The impact contributors were grouped into 6 processes; (i) substrate preparation (ii) sterilization, (iii) inoculation, (iv) incubation and fruiting, (v) harvest, (vi) waste management. It can be seen that the substrate preparation, sterilization and waste management are the main impact contributors.

TABLE II: ENVIRONMENTAL IMPACTS OF $1 \mathrm{KG}$ OF SHIITAKE FROM.

\begin{tabular}{|l|l|c|}
\hline Impact category & Unit & Impact \\
\hline Climate change & $\mathrm{kg} \mathrm{CO}$ eq & 1.8671 \\
\hline Ozone depletion & $\mathrm{kg} \mathrm{CFC}-11 \mathrm{eq}$ & $1.44 \times 10^{-8}$ \\
\hline Terrestrial acidification & $\mathrm{kg} \mathrm{SO}$ eq & 0.0195 \\
\hline Human toxicity & $\mathrm{kg} \mathrm{1,4-DB} \mathrm{eq}$ & 0.0563 \\
\hline Photochemical oxidant formation & $\mathrm{kg} \mathrm{NMVOC}$ & 0.0483 \\
\hline Particulate matter formation & $\mathrm{kg} \mathrm{PM10} \mathrm{eq}$ & 0.0067 \\
\hline Terrestrial ecotoxicity & $\mathrm{kg} \mathrm{1,4-DB} \mathrm{eq}$ & 0.0005 \\
\hline Freshwater ecotoxicity & $\mathrm{kg} \mathrm{1,4-DB} \mathrm{eq}$ & 0.0053 \\
\hline Marine ecotoxicity & $\mathrm{kg} 1,4-\mathrm{DB}$ eq & 0.0022 \\
\hline
\end{tabular}

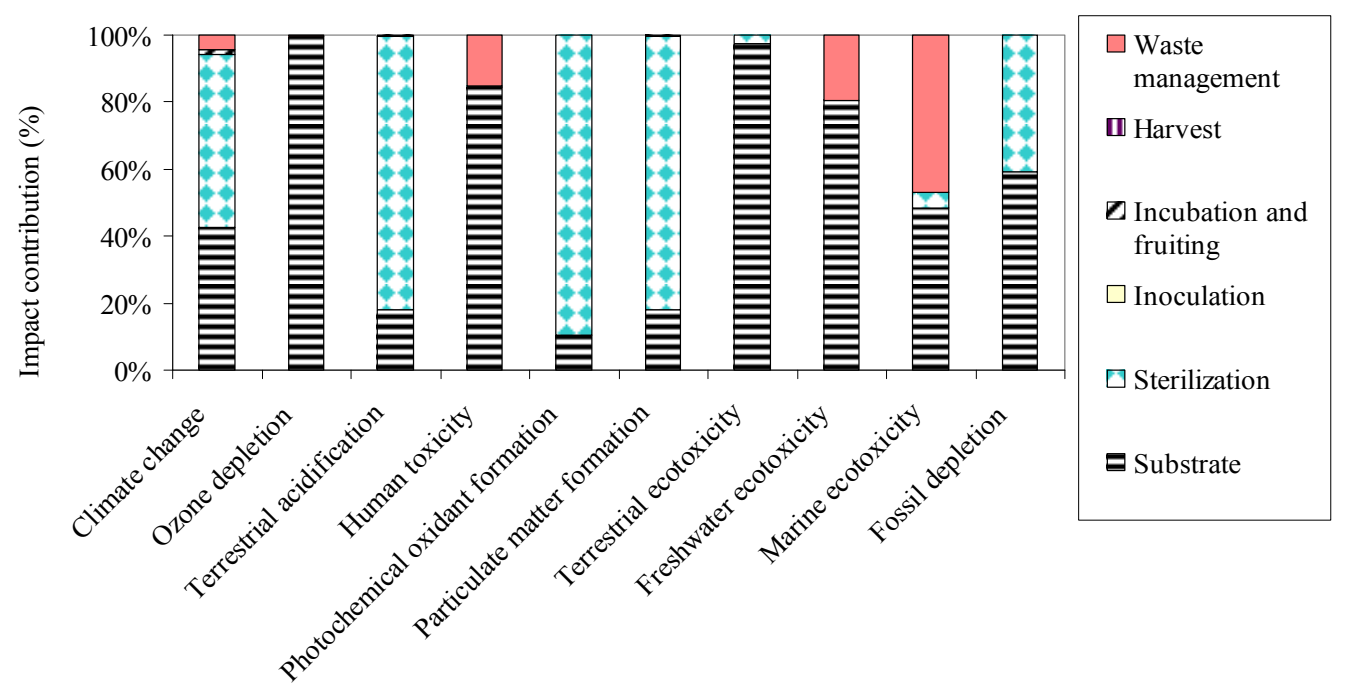

Impact category

Fig. 2. Impact contributions from the components of $1 \mathrm{~kg}$ shiitake. 


\section{A. Environmental Impact from Substrate Preparation}

The contributions of environmental impacts from the substrate preparation process are shown in Fig. 3. The impact contributors were the substrate ingredients (sawdust, rice bran, magnesium sulfate, gypsum, lime, sugar), plastic bag, neck ring and transportation of these materials. It can be seen that the rice bran, sugar and transportation were the main impact contributors.

Shiitake farmers might not be able to improve the rice bran and sugar to be more environmental friendly. However, farmers can try to optimize the content of rice bran and sugar. The replacement of rice bran with rice straw, corn cob, maize and other agricultural by-products having relatively low environmental impacts might be an alternatives [17]. It was reported that mixing wheat straw in the substrate improved shiitake yield [3]. Since certain agricultural by-products should be milled or ground before being used as substrate, additional energy and expense is needed. Environmental performance of shiitake with innovated substrate should be assessed.

Fig. 3 shows that $40 \%$ of the climate change impact came from transportation. Transportation also caused half of terrestrial acidification and particulate matter formation impacts. Transportation shared as high as $65 \%$ of photochemical oxidant formation impact. Transportation played important role because most of the sawdust was transported from the southern part of Thailand which is about $1200-1500 \mathrm{~km}$ from the shiitake farms. The environmental performance of shiitake farm can be largely improved if the sawdust sources are close to the farms.

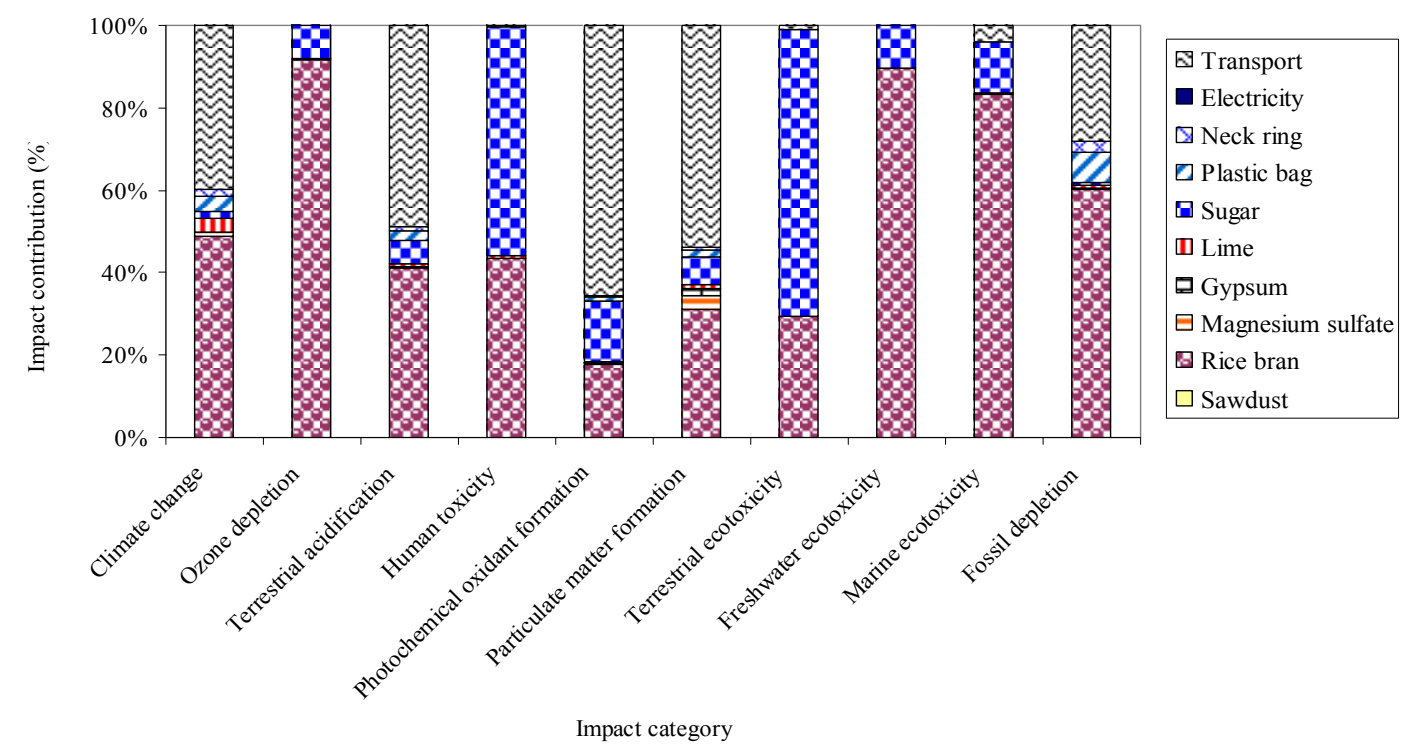

Fig. 3. Impact contributions from the substrate that yield $1 \mathrm{~kg}$ of shiitake.

\section{B. Environmental Impact from Sterilization}

The fuel used for steam generation used in sterilization was sawdust and firewood. Transportation of the fuel and emissions from fuel burning were the main causes of the environmental impacts in sterilization process as shown in Fig. 4. The combustion of firewood and sawdust released $\mathrm{CO}_{2}, \mathrm{CH}_{4}, \mathrm{~N}_{2} \mathrm{O}, \mathrm{CO}, \mathrm{NOx}, \mathrm{SO}_{2}, \mathrm{NMVOC}$ and PM10. The $\mathrm{CO}_{2}$ from biomass burning is treated as carbon neutral (zero). $\mathrm{CH}_{4}$ and $\mathrm{N}_{2} \mathrm{O}$ are greenhouse gases, inducing climate change. $\mathrm{NOx}$ and $\mathrm{SO}_{2}$ caused terrestrial acidification, whereas $\mathrm{CO}$, $\mathrm{CH}_{4}, \mathrm{NOx}, \mathrm{SO}_{2}, \mathrm{NMVOC}$ caused photochemical oxidant formation and $\mathrm{NOx}, \mathrm{SO}_{2}$ and $\mathrm{PM} 10$ caused particulate matter formation. Combustions of natural gas and LPG release relatively low amounts of $\mathrm{CO}$, NOx, SOx, NMVOC and PM10, as shown in Table III. The global warming potentials of $1 \mathrm{~kg}$ of $\mathrm{CO}_{2}, \mathrm{CH}_{4}$ and $\mathrm{N}_{2} \mathrm{O}$ are 1,25 and $298 \mathrm{~kg} \mathrm{CO}_{2}$ eq, respectively [14]. Since $\mathrm{CO}_{2}$ emission from wood is treated as zero (carbon neutral), the climate change caused by wood combustion is $8,692 \mathrm{~kg} \mathrm{CO} 2 \mathrm{eq} / \mathrm{TJ}$ whereas the climate change caused by natural gas and LPG is 56,255 and 63,255 $\mathrm{kg} \mathrm{CO} 2 \mathrm{eq} / \mathrm{TJ}$, respectively. The replacement of firewood and sawdust with natural gas and LPG will reduce the impacts in the categories of terrestrial acidification, photochemical oxidant formation and particulate matter formation, but will increase the impact of climate change as well as fossil depletion. The prevention of heat loss is more practical for farmers. This will reduce the use of fuel and subsequently environmental impacts. Traditional cultivation of shiitake on logs does not need sterilization and plastic bag. The comparison of environmental performance of these two technologies is interesting.

TABLE III: GASEOUS EMISSIONS FROM FUEL COMBUSTION [10], [11]

\begin{tabular}{|c|c|c|c|c|c|c|c|c|c|}
\hline \multirow{2}{*}{ Fuel type } & \multicolumn{9}{|c|}{$\mathrm{kg} / \mathrm{TJ}$} \\
\cline { 2 - 10 } & NOx & $\mathrm{CO}$ & NMVOC & $\mathrm{SO}_{2}$ & TSP & PM10 & $\mathrm{CO}_{2}$ & $\mathrm{CH}_{4}$ & $\mathrm{~N}_{2} \mathrm{O}$ \\
\hline Wood & 150 & 1600 & 146 & 38.4 & 156 & 150 & 112,000 & 300 & 4 \\
\hline Natural gas & 70 & 25 & 2.5 & 0.5 & 0.5 & 0.5 & 56,100 & 5 & 0.1 \\
\hline LPG & 100 & 40 & 10 & 140 & 27.5 & 21.5 & 63,100 & 5 & 0.1 \\
\hline
\end{tabular}




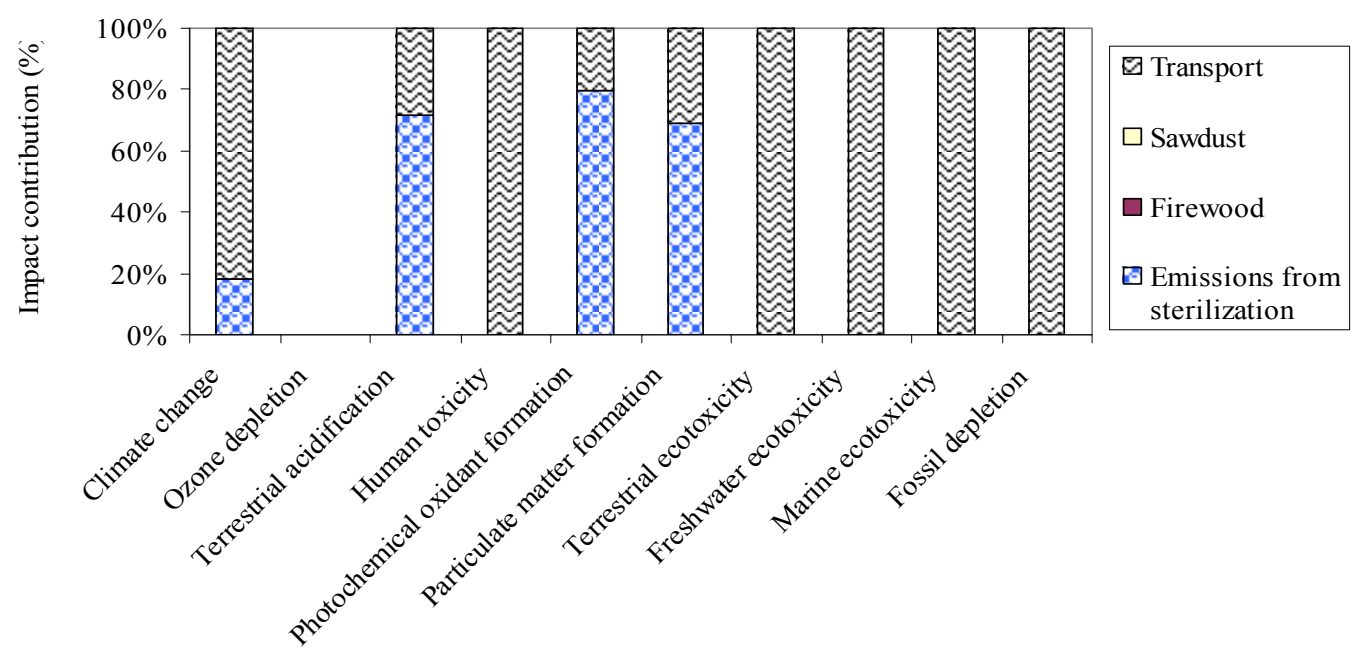

Impact category

Fig. 4. Impact contributions from sterilization of the substrate that yield $1 \mathrm{~kg}$ of shiitake.

\section{Environmental Impact from Waste Management}

Fig. 2 shows that waste management causes impacts in toxicity categories. This came from burning of plastic bags and neck rings. The inventory of polypropylene incineration of Ecoinvent database in SimaPro 7.2.3 software reveals that there are heavy metal, cyanide, bromine to air and to water [13]. These substances have potential to induce the impacts in the categories of human toxicity, freshwater ecotoxicity and marine ecotoxicity. The environmental impacts of incineration and landfill of polypropylene were analyzed using Ecoinvent database in SimaPro 7.2.3 software. The result shows that the landfill of polypropylene can create higher impacts than the incineration in the categories of toxicity but lower impact in the climate change as shown in Table IV. The recycling of spent plastic bags and neck rings should be considered.

\section{Potential Reduction of Environmental Impacts}

If the transport distance of sawdust is $100 \mathrm{~km}$ and if the spent bags and neck rings are not burnt but used to make recycled plastic, the environmental impacts of shiitake will be largely reduced as shown in Table $\mathrm{V}$. The reduction of 58, 52 and $53 \%$ of the impacts in the categories of climate change, fossil depletion and marine ecotoxicity can be obtained, respectively. One third reduction of the impacts in the categories of terrestrial acidification and particulate matter formation are possible.

TABLE IV: ENVIRONMENTAL IMPACTS OF INCINERATION AND LANDFILL OF 1 KG PROLYPROPYLENE.

\begin{tabular}{|l|l|c|c|}
\hline Impact category & Unit & Incineration & Landfill \\
\hline Climate change & $\mathrm{kg} \mathrm{CO} 2 \mathrm{eq}$ & 2.5348 & 0.0968 \\
\hline Ozone depletion & $\mathrm{kg} \mathrm{CFC}-11 \mathrm{eq}$ & $1.49 \times 10^{-9}$ & $3.10 \times 10^{-9}$ \\
\hline Terrestrial acidification & $\mathrm{kg} \mathrm{SO} 2 \mathrm{eq}$ & $2.54 \times 10^{-4}$ & $7.44 \times 10^{-5}$ \\
\hline Human toxicity & $\mathrm{kg} 1,4-\mathrm{DB}$ eq & 0.2618 & 0.3508 \\
\hline Photochemical oxidant formation & $\mathrm{kg} \mathrm{NMVOC}$ & 0.0005 & 0.0002 \\
\hline Particulate matter formation & $\mathrm{kg} \mathrm{PM} 10 \mathrm{eq}$ & $1.04 \times 10^{-4}$ & $3.57 \times 10^{-5}$ \\
\hline Terrestrial ecotoxicity & $\mathrm{kg} 1,4-\mathrm{DB}$ eq & $7.32 \times 10^{-6}$ & $6.12 \times 10^{-6}$ \\
\hline Freshwater ecotoxicity & $\mathrm{kg} 1,4-\mathrm{DB}$ eq & 0.0322 & 0.0553 \\
\hline Marine ecotoxicity & $\mathrm{kg} 1,4-\mathrm{DB}$ eq & 0.0317 & 0.0542 \\
\hline Fossil depletion & $\mathrm{kg} \mathrm{oil} \mathrm{eq}$ & 0.0041 & 0.0067 \\
\hline
\end{tabular}

TABLE V: ENVIRONMENTAL IMPACTS OF 1 KG OF SHIITAKE USING LCI AS THE SCENARIO.

\begin{tabular}{|l|l|c|c|}
\hline Impact category & Unit & Scenario & \% Reduction \\
\hline Climate change & $\mathrm{kg} \mathrm{CO}$ eq & 0.7818 & 58 \\
\hline Ozone depletion & $\mathrm{kg} \mathrm{CFC}-11 \mathrm{eq}$ & $1.43 \times 10^{-8}$ & 0.3 \\
\hline Terrestrial acidification & $\mathrm{kg} \mathrm{SO}$ eq & 0.0137 & 30 \\
\hline Human toxicity & $\mathrm{kg} \mathrm{1,4-DB} \mathrm{eq}$ & 0.0475 & 16 \\
\hline Photochemical oxidant formation & $\mathrm{kg} \mathrm{NMVOC}$ & 0.0373 & 23 \\
\hline Particulate matter formation & $\mathrm{kg} \mathrm{PM10} \mathrm{eq}$ & 0.0045 & 33 \\
\hline Terrestrial ecotoxicity & $\mathrm{kg} \mathrm{1,4-DB} \mathrm{eq}$ & 0.0005 & 3 \\
\hline Freshwater ecotoxicity & $\mathrm{kg} \mathrm{1,4-DB} \mathrm{eq}$ & 0.0043 & 19 \\
\hline Marine ecotoxicity & $\mathrm{kg} \mathrm{1,4-DB} \mathrm{eq}$ & 0.0010 & 53 \\
\hline Fossil depletion & $\mathrm{kg} \mathrm{oil} \mathrm{eq}$ & 0.2804 & 52 \\
\hline
\end{tabular}




\section{CONCLUSION}

The environmental impacts of shiitake were higher than those of everyday vegetables but lower than average meat. There are plenty of rooms for improving environmental performance of shiitake: (i) using the sawdust from near suppliers, (ii) preventing heat loss during sterilization and (iii) sending spent bags and neck rings to recycled plastic industry. Traditional cultivation of shiitake on logs does not need sterilization, plastic bag and neck ring. Research on improvement of traditional cultivation as well as long-life substrate and bag reusing are interesting. As shiitake is largely produced around the world, a small fraction of the impact reduction will largely contribute to environmental situation of the world.

\section{ACKNOWLEDGMENT}

This work was accomplished through the financial support of National Science and Technology Development Agency (NSDTA) Thailand, under the Thailand National LCI Database Project. We acknowledge Payao University for their effort in data collection of shiitake inventories. We also appreciate Assoc. Prof. Dr. Thumrongrut Mungcharoen and Ms. Chantana Yuvaniyama, the experts at National Science and Development Agency (NSTDA), for the advice on the Thai National Life Cycle Inventory Database Development Project.

\section{REFERENCES}

[1] R. Hearst, D. Nelson, G. McCollum, B. C. Millar, Y. Maeda, C. E. Goldsmith et al., "An examination of antibacterial and antifungal properties of constituents of Shiitake (Lentinula edodes) and Oyster (Pleurotus ostreatus) mushrooms," Complementary Therapies in Clinical Practice, vol. 15, no. 1, pp. 5-7, 2009.

[2] L. Fan, H. Pan, Y. Wu, and K. W. Choi, "Shitake bag cultivation in China," Mushroom Growers' Handbook 2, ch. 4, pp. 121-131, 2005.

[3] D. J. Royse and J. E. Sanchez, "Ground wheat straw as a substitute for portions of oak wood chips used in shiitake (Lentinula edodes) substrate formulae," Bioresource Technology, vol. 98, pp. 2137-2141, 2007.

[4] A. W. Chen, "Shiitake bag cultivation," Mushroom Growers' Handbook 2, ch. 4, pp. 73-87, 2005.

[5] D. L. Rinker, "Recycling spent shiitake substrate," Mushroom growers' Handbook 2, ch. 7, pp. 189-186, 2005.

[6] P. Arampongpan. (2013). Shiitake cultivation from saw dust, Department of Agriculture. [Online]. Available: http://www.doae.go.th/library/html/detail/had-hom/hom2.htm\#n1.

[7] G. Finnveden, M. Z. Hauschild, T. Ekvall, J. Guine, R. Heijungs, S. Hellweg, et al., "Recent developments in life cycle assessment," Journal of Environmental Management, vol. 91, pp. 1-21, 2009.

[8] R. Tongpool, A. Jirajariyavech, C. Yuvaniyama, and T. Mungcharoen, "Analysis of steel production in Thailand: environmental impacts and solutions," Energy, vol. 35, pp. 4192-4200, 2010.

[9] R. Tongpool, N. Phanichavalit, C. Yuvaniyama, and T. Mungcharoen, "Improvement of the environmental performance of broiler feeds: a study via life cycle assessment," Journal of Cleaner Production, vol. 35 , pp. 16-24, 2012.
[10] IPCC, "Energy," in 2006 IPCC Guidelines for National Greenhouse Gas Inventories, H. S. Eggleston, L. Buendia, K. Miwa, T. Ngara, K. Tanabe, Ed. Japan: IGES, 2006, vol. 2, ch. 2, pp. 2-22. 2006.

[11] K. Kubica, B. Paradiz, P. Dilara, Z. Klimont, S. Kakareka, B. Debsk, M. Woodfield, and R. Stewart, "Small Combustion", in EMEP/EEA Air Pollutant Emission Inventory Guidebook 2009, European Environmental Agency, Copenhagen, pp. 26-28, 2009.

[12] H. Nadsathaporn, "Environmental life cycle assessment of rice products," M. Eng. Thesis, Faculty of Environmental Engineering, Suranaree University of Technology. Nakorn Ratchasima, Thailand, 2007.

[13] PRé Consultants, SimaPro, The Netherlands, 2013.

[14] M. Goedkoop, R. Heijungs, M. Huijbregts, A. De Schryver, J. Struijs, and R. V. Zelm, "ReCiPe 2008: A Life cycle impact assessment method which comprises harmonized category indicators at the midpoint and the endpoint level -report I - characterization," 2009.

[15] R. Tongpool, C. Yuvaniyama, and T. Mungcharoen, "The sustainable production of food crops via eco-efficiency," International Proceedings of 6th Dubrovnik Conference on Sustainable Development of Energy, Water and Environment Systems, Dubrovnik, Croatia, pp. 15, 2011.

[16] D. Nijdam, T. Rood, and H. Westhoek, "The price of protein: Review of land use and carbon footprints from life cycle assessments of animal food products and their substitutes," Food Policy, vol. 37, pp. 760-770, 2012.

[17] M. Moonmoon, N. J. Shelly, Md. A. Khan, Md. N. Uddin, K. Hossain, M. Tania, and S. Ahmed, "Effects of different levels of wheat bran, rice bran and maize powder supplementation with saw dust on the production of shiitake mushroom (Lentinus edodes (Berk.) Singer," Saudi Journal of Biological Sciences, vol. 18, no. 4, pp. 323-328, 2011.

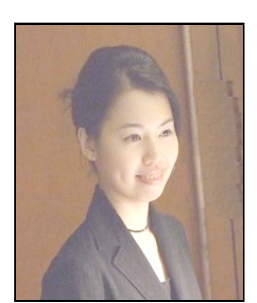

Rungnapa Tongpool was born in Thailand. She graduated from Kasetsart University, Thailand and got her Master and PhD degree in Materials Science in 2000 from University of Manchester Institute of Science and Technology (UMIST), Manchester, UK.

She started her career as a researcher at National Metal and Materials Technology Center (MTEC), Thailand in 2000. In the first seven years, her work had focused on materials research, such as gas sensing materials, photocatalyst, dye sensitised solar cell, UV and IR preventive film. Then she joined life cycle assessment (LCA) laboratory at MTEC, carrying on national life cycle inventory (LCI) establishment. The national LCI has been applied in carbon footprint calculation and environmental assessment of commercial products. She is one of the committee, setting up national carbon footprint scheme. Now she holds the position as LCA lab head and principal researcher. She also gives consultancy to private companies on carbon footprint, LCA for product development.

Dr. Tongpool achieved gold medal from Agriculture-HorticultureGardening Section, $34^{\text {th }}$ International Exhibition of Inventions, New Techniques and Products, Geneva, in 2006, on her invention "zip-lock paper bag". She is one of the authors of the book "Establishment of Thai National Life Cycle Inventory Database, Pathumthani, NSTDA, 2012 (ISBN: 978-616-12-0176- 0) according to her experience. Her recent article is "Improvement of the environmental performance of broiler feeds: a study via life cycle assessment”, published in Journal of Cleaner Production, 2012.

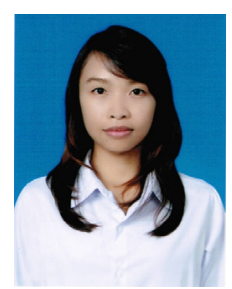

Patcharaporn Pongpat is an engineer in Life Cycle Assessment Laboratory, National Metal and Materials Technology Centre (MTEC), National Science and Technology Development Agency (NSTDA). She completed her Master degree in energy engineering at Chiang Mai University, Thailand in 2012.

She started working as an engineer at life cycle assessment (LCA) laboratory at MTEC since 2012. Her work focuses on national life cycle inventory (LCI) establishment and research consultancy for private companies relating to carbon footprint and environmental impact assessment. 